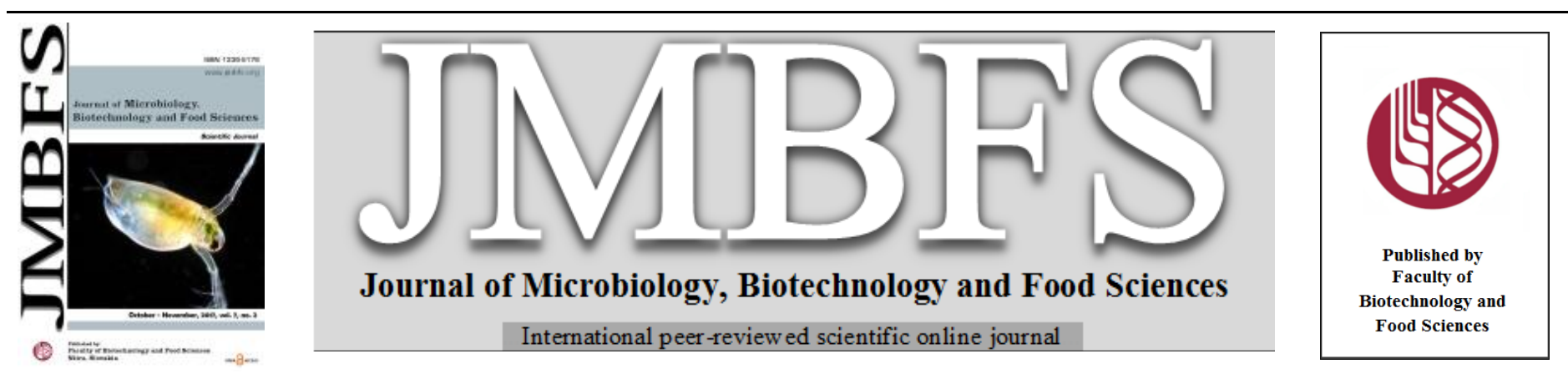

\title{
DEVELOPMENT OF SNACK CRACKERS INCORPORATED WITH DEFATTED COCONUT FLOUR
}

\author{
Sachithra Mihiranie $*^{1}$, Mithila Jayasundera ${ }^{2}$ and Niranjalie Perera ${ }^{1}$ \\ Address(es): \\ ${ }^{1}$ Department of Food Science and Technology, Faculty of Livestock, Fisheries and Nutrition, Wayamba University of Sri Lanka, Makandura, Gonawila, Sri Lanka \\ (NWP) 60170.
}

${ }^{2}$ Coconut Processing Research Division, Coconut Research Institute, Lunuwila, Sri Lanka.

*Corresponding author: sachithra.mihiranie@gmail.com

doi: 10.15414/jmbfs.2017.7.2.153-159

ARTICLE INFO

Received 30. 1. 2017

Revised 14. 5. 2017

Accepted 12. 9. 2017

Published 1. 10. 2017

Regular article OPEN $\partial$ ACCESS

\begin{abstract}
Recently, consumer demand has increased for healthy snacks. Snack crackers are popular as healthy snacks and there is a high potential to enhance the nutritional value by incorporating natural ingredients. In the present study, the dietary fiber content of the snack crackers was improved by incorporating defatted coconut flour. Chemical and functional properties of defatted coconut flour and all-purpose wheat flour were studied. Snack crackers were prepared by incorporating defatted coconut flour into wheat flour at 10, 20, 30 and $40 \%$ (w/w) levels. Sensory evaluation was conducted by using a 5-point hedonic scale with 31 panelists based on color, crispiness, texture, taste and overall acceptance. Physico-chemical characteristics and shelf life studies were carried out after packing in triple laminated aluminum foil and stored under ambient conditions. Defatted coconut flour was characterized with significantly higher crude fiber (17.69\%), protein (22.10\%) and mineral content (6.17\%) than all-purpose wheat flour. The bulk density, water and oil holding capacities of defatted coconut flour were significantly higher than all-purpose wheat flour $(\mathrm{p}<0.05)$. All prepared snack crackers were contained significantly high $(\mathrm{p}<0.05)$ content of protein, mineral and crude fiber compared to control ( $100 \%$ wheat flour). The keeping quality was decreased with increasing level of defatted coconut flour. Collectively, the results revealed that up to $20 \%(\mathrm{w} / \mathrm{w})$ defatted coconut flour can be incorporated in the formulation of healthy snack crackers without compromising physicochemical and sensory attributes.
\end{abstract}

Keywords: Deaffted coconut flour, Dietary fiber, Spread ratio, Snack crackers

\section{INTRODUCTION}

Snack food consumption has increased as a result of urbanization and modernization. However, most of the snacks are contained high amount of fats, sugar, and salts and least amount of dietary fiber which can be caused health problems (Williams et al., 2008). Due to that, the consumer demand of healthy snacks is increasing. Therefore, snack crackers can be considered as one of the most desirable snacks due to their good eating quality and superior nutritional properties.

Crackers are biscuits having typical flaky inner layers (SLS 251: 2010). Crackers contain little sugar, moderate levels of fat and relatively low levels of salt (Han et al., 2010). Consequently, crackers can be used as a good substitute for sweeter snacks. Along with, crackers can be utilized as a source of incorporation of different nutritionally rich ingredients for the diversification (Sudha et al. 2007) Among these added ingredients, dietary fiber has gained tremendous attention. Valencia et al. (2006) reported that there is an increasing demand for high fiber food products in order to overcome health problems such as hypertension, diabetes, and colon cancer.

The major reason for the less consumption of dietary fiber may be due to the less palatability of fiber rich foods. Dietary fiber is naturally contained only in foods derived from plants, fruits, vegetables, grains and legumes. In addition, Trinidad et al. (2006) showed that defatted coconut flour is another rich source of dietary fiber. However, all purpose wheat flour is not a good source of dietary fiber, defatted coconut flour can be incorporated into wheat flour in order to improve its health benefits. Therefore, it is an excellent way to increase daily fiber intake. Defatted coconut flour (DCF) is made out of coconut residue remained after the extraction of virgin coconut oil. Defatted coconut flour is now recognized as a good resource with significant potential health benefits as it contains complex carbohydrates, dietary fiber, high protein (Gunathilake $\boldsymbol{e t}$ al., 2009). It is also gluten-free and has a low glycemic index; therefore it is good for people suffering from diabetes, cardiovascular disease, and celiac disease. Therefore, defatted coconut flour is a better healthy alternative to wheat flour. Some studies have proved that fiber-rich defatted coconut flour can be used to prepare food products such as bread, biscuits, noodles and snack bars (Abeyrathne and
Gunathilake 2008; Gunathilake et al., 2009). Therefore, there is a great opportunity to develop fiber rich and healthy snack crackers incorporated into defatted coconut flour.

In addition, nowadays emerging beneficial oil that comes into the picture of the world is virgin coconut oil. The major difference between coconut oil and virgin coconut oil is the method of extraction. Virgin coconut oil has many advantages, which includes the health benefits of the retained vitamins and antioxidants, the antimicrobial and antiviral activity of the Lauric acid components and through its easy digestibility from the medium chain fatty acids (Marina et al., 2009). Along with the antioxidant activity of virgin coconut oil helps to delay the oxidative rancidity of food products (Nevin et al., 2006). Therefore, it is a good fat source of the food preparation instead of other oil types, especially for palm oil.

Present dietary scenario necessitates exploring the possibility of incorporating novel ingredients in commonly consumed foods. According to the current nutritional quality of snack crackers and growing demand for crackers, it seems worthwhile to take the effort in enhancing the nutritional value of crackers. The present study was undertaken with the objectives to compare the functional properties of defatted coconut flour with all purpose wheat flour and incorporate it into snack crackers to assess the quality and acceptability of snack crackers.

\section{MATERIAL AND METHODS}

The experiment was conducted in the laboratory of the Coconut Processing Research Division, Processing Research Institute, Lunuwila, Sri Lanka and Wayamba university of Sri Lanka, Makandura, Gonawila, Sri Lanka.

\section{Preparation of defatted coconut flour}

The defatted coconut flour was obtained from the coconut residue after extracting virgin coconut oil and was ground into fine particles using a grinder (model HL 3294/C Phillips) and was sieved using a stainless steel sieve (mesh size $0.25 \mathrm{~mm}$ ) to obtain defatted coconut flour. 


\section{Other ingredients}

All purpose wheat flour (WF) was purchased from a local supermarket in Sri Lanka under the brand name of "Prima". The remaining ingredients required for the snack crackers formulation were purchased from local market were salt, sugar, baking powder, virgin coconut oil, margarine, milk powder, malt extract and lecithin.

\section{Analysis of proximate composition of flour}

Flour samples (DCF and WF) were analyzed for moisture (Standard oven dry method), proteins (Kjeldahl method), fat (Soxhlet extraction), crude fiber (Weende method), carbohydrate content and ash content according to the methods prescribed by AOAC, 1999.

\section{Analysis of functional properties of flour}

\section{Bulk density (BD)}

The bulk density was determined according to the method described by Okaka and Potter (1977). The sample (50 g) was put into a $100 \mathrm{ml}$ graduated cylinder and tapped 20-30 times. The bulk density was calculated as weight per unit volume of sample.

\section{Water and oil holding capacity (WHC/ ORC)}

The water and oil holding capacities were determined by the method of Sosulski et al. (1976). The cracker sample $1.0 \mathrm{~g}$ was mixed with $10 \mathrm{ml}$ distilled water or refined soybean oil, kept at ambient temperature for $30 \mathrm{~min}$ and centrifuged for $10 \mathrm{~min}$ at $2000 \times \mathrm{g}$. Water or oil holding capacity was expressed as percent water or oil bound per gram of the sample.

\section{Foaming capacity (FC)}

One gram of cracker sample was whipped with $100 \mathrm{ml}$ distilled water for $5 \mathrm{~min}$ in a blender at $500 \mathrm{rpm}$ and poured into a $250 \mathrm{ml}$ graduated cylinder. The volume of foam at 30 seconds after whipping was expressed as the foaming capacity (Chinma et al., 2008).

\section{Preparation of flour blends}

All purpose wheat flour was substituted by defatted coconut flour at $0,10,20,30$ and $40 \%$ levels, w/w (flour basis).

\section{Snack cracker preparation}

Table 1 Formulations for snack crackers $\left(\mathbf{T}_{0}-100 \% \mathrm{WF}, \mathbf{T}_{1}-10 \%\right.$ DCF, $\mathbf{T}_{2}-20 \% \mathrm{DCF}, \mathbf{T}_{3}-30 \%$ DCF and $\mathbf{T}_{4}-40 \%$

\begin{tabular}{|c|c|c|c|c|c|c|c|c|c|c|}
\hline Treatment & $\begin{array}{l}\text { Wheat } \\
\text { Flour } \\
\text { (g) }\end{array}$ & $\begin{array}{l}\text { Coconut } \\
\text { Flour } \\
\text { (g) }\end{array}$ & $\begin{array}{l}\text { Yeast } \\
\text { (g) }\end{array}$ & $\begin{array}{l}\text { Malt } \\
\text { Extract } \\
\text { (g) }\end{array}$ & $\begin{array}{l}\text { Shortening } \\
\text { (g) }\end{array}$ & $\begin{array}{l}\text { Baking } \\
\text { Powder } \\
\text { (g) }\end{array}$ & $\begin{array}{l}\text { Lecithin } \\
\text { (g) }\end{array}$ & $\begin{array}{l}\text { Water } \\
\text { (ml) }\end{array}$ & $\begin{array}{l}\text { Palm } \\
\text { oil } \\
(\mathrm{ml})\end{array}$ & $\begin{array}{l}\text { Virgin } \\
\text { coconut } \\
\text { oil }(\mathrm{ml})\end{array}$ \\
\hline $\mathbf{T}_{\mathbf{o}}$ & 100 & 0 & 0.5 & 0.5 & 17 & 2.5 & 0.25 & 36 & 10 & 0 \\
\hline $\mathbf{T}_{1}$ & 90 & 10 & 0.5 & 0.5 & 17 & 2.5 & 0.25 & 36 & 0 & 10 \\
\hline $\mathbf{T}_{2}$ & 80 & 20 & 0.5 & 0.5 & 17 & 2.5 & 0.25 & 36 & 0 & 10 \\
\hline $\mathbf{T}_{3}$ & 70 & 30 & 0.5 & 0.5 & 17 & 2.5 & 0.25 & 36 & 0 & 10 \\
\hline $\mathbf{T}_{4}$ & 60 & 40 & 0.5 & 0.5 & 17 & 2.5 & 0.25 & 36 & 0 & 10 \\
\hline
\end{tabular}

All the ingredients used for the cracker preparation were presented in Table 1. The snack crackers were prepared according to the procedure of Han $\boldsymbol{e t}$ al (2010) with some modifications. A portion of the flour blend and portions of other ingredient were mixed and the dough was allowed to ferment in troughs at room temperature for 16 to 19 hours. After fermentation, the sponge was added to the remaining ingredients and mixed for 3 to 7 minutes. After mixing, the dough was further fermented in troughs for 3 to 6 hours. The fermented dough was sheeted and laminated into 7 or 8 layers with a combined thickness of about 0.1 inches $(2 \mathrm{~mm})$. Circular crackers (diameter $-4 \mathrm{~cm}$ ) were cut from the dough sheet using a dough cutter and transferred onto a mesh-wired baking sheet. The dough was also docked, or stamped with pins, to form the pattern of holes. Baking takes place at about $160^{\circ} \mathrm{C}$ for 20 minutes. After baking, the snack crackers were allowed to cool and packed in moisture-proof triple laminated Aluminum bags.

\section{Sensory evaluation}

Sensory evaluation was conducted using 31 semi-trained panelists who were asked to score color, texture, crispiness, flavour, and overall acceptability on 5 point hedonic scales $(1=$ dislike extremely, $5=$ like extremely).

The results of the sensory evaluation were analyzed using the nonparametric Friedman rank test in the Minitab software package version 15.0.

\section{Analysis of physical characteristics of snack crackers}

Physical properties of the snack crackers were determined as described by Baljeet et al. (2010). The diameter of snack crackers was measured by laying six snack crackers edge to edge with the help of a scale rotating them $90^{\circ}$ and again measuring the diameter of six snack crackers $(\mathrm{cm})$ and then taking the average value. Thickness was measured by stacking six snack crackers on top of each other and taking average thickness $(\mathrm{cm})$. The weight of crackers was measured as average values of four individual snack crackers with the help of a digital weighing balance. Spread ratio was calculated by dividing the average value of the diameter by average value of the thickness of snack crackers.

\section{Analysis of proximate composition of snack crackers}

Moisture content was determined using standard oven (Gallenkamp, SANYO Gallenkamp PPLC, U.K.) method by drying at $105^{\circ} \mathrm{C}$ for 4 hours and then to constant weight (SLS 251:1991); Test for fat content was carried out by soxhlet extraction using petroleum ether $\left(40^{\circ} \mathrm{C}-60^{\circ} \mathrm{C}\right)$ as solvent (Pearson, 1973); Mineral content determination was done by dry ashing method (Pearson, 1973); Crude protein content by Kjeldahl method (AOAC, 1999); Crude fiber content by Weende method (AOAC, 1999) and determination of energy using Bomb calorimeter (AOAC, 1995).

\section{Shelf life studies}

Analysis of shelf life studies was carried out once in two weeks for a period of three months after packing in triple laminated Aluminum foil and stored under ambient conditions. Moisture content was determined using standard oven method by drying at $105^{\circ} \mathrm{C}$ for 4 hours and then to constant weight (SLS 251:1991). Oils of cracker samples were extracted by Soxhlet extraction procedure using petroleum ether $\left(40^{\circ} \mathrm{C}-60^{\circ} \mathrm{C}\right)$ as solvent (Pearson 1973). Peroxide value (PV) of oil was determined by dissolving oil sample $(5 \mathrm{~g})$ in acetic acid - chloroform solution and titrated with $0.01 \mathrm{~N}$ Sodium Thiosulphate in the presence of saturated potassium iodide and starch indicator. The free fatty acid content of oil was determined by dissolving oil sample $(5 \mathrm{~g})$ in $95 \%$ Ethyl Alcohol followed by titration with Sodium Hydroxide $(0.1 \mathrm{~N})$ using phenolphthalein indicator. Enumeration of aerobic colony count was done by incubating micro organisms in nutrient agar (NA) medium at $37^{\circ} \mathrm{C}$ for 48 hours and the yeast and mould count was done by incubating in potato dextrose agar (PDA) medium with $0.01 \%$ Chloramphenicol held at room temperature (SLS 256:1991).

\section{Statistical analysis}

Analysis of variance was carried out to find out the significant differences among cracker samples using one-way analysis of variance (ANOVA) using the Minitab 15 software version.

\section{RESULTS AND DISCUSSION}

\section{Proximate composition of all purpose Wheat Flour (WF) and Defatted} coconut flour (DCF)

Proximate composition of all purpose WF and DCF are presented in Table 2. It was found that DCF had a significantly higher content of protein $(22.10 \%)$, fat $(8.04 \%)$, ash $(6.17 \%)$, crude fiber $(17.69 \%)$ and lower content of carbohydrate $(41.06 \%)$ and moisture $(10.66 \%)$ in comparison to all purpose WF. On the other hand, all-purpose WF contained lower content of protein $(9.57 \%)$, fat $(0.79 \%)$, ash $(0.49 \%)$, crude fiber $(0.51 \%)$ and higher content of carbohydrate $(77.98 \%)$. 
Table 2 Proximate composition of all purpose wheat flour and defatted coconut flour

\begin{tabular}{lcc}
\hline Parameter & $\begin{array}{c}\text { Defatted coconut } \\
\text { Flour }\end{array}$ & $\begin{array}{c}\text { All purpose Wheat } \\
\text { Flour }\end{array}$ \\
\hline Moisture & $4.94 \pm 0.02^{\mathrm{a}}$ & $10.66 \pm 0.304^{\mathrm{b}}$ \\
Ash & $6.17 \pm 0.03^{\mathrm{a}}$ & $0.49 \pm 0.07^{\mathrm{b}}$ \\
Fat & $8.04 \pm 0.49^{\mathrm{a}}$ & $0.79 \pm 0.06^{\mathrm{b}}$ \\
Protein & $22.10 \pm 2.92^{\mathrm{a}}$ & $9.57 \pm 2.20^{\mathrm{b}}$ \\
Crude fiber & $17.69 \pm 1.45^{\mathrm{a}}$ & $0.51 \pm 0.05^{\mathrm{b}}$ \\
*Carbohydrates & 41.06 & 77.98 \\
\hline
\end{tabular}

The values are mean \pm S.D of three independent determinations. The means with different superscripts in a row differ significantly $(\mathrm{p} \leq 0.05) . *$ Calculated by difference method.

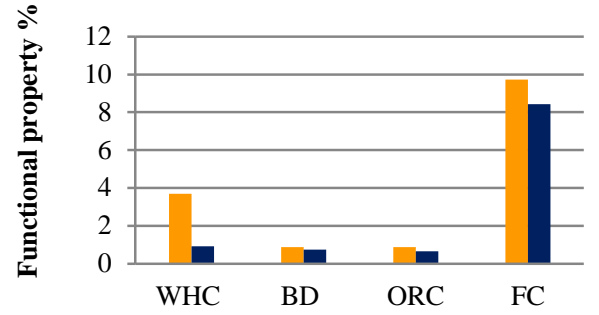

- Defatted Coconut flour

- All purpose Wheat flour

Type of functional property

Figure 1 Functional properties of all purpose wheat flour and coconut flour
The results from the analysis of functional properties of DCF and WF are summarized in Figure 1. Functional properties of the DCF showed significant differences compared to all-purpose WF. As a hydration parameter of the flour, the water holding capacity (WHC) of DCF was significantly higher than that of WF $(p \leq 0.05)$. The value of the bulking density and the oil retention capacity of DCF was significantly higher than those of WF $(\mathrm{p}<0.05)$. With respect to the foaming capacity, statistically, there was no significant difference between DCF and WF. However, the foaming capacity of DCF was higher than WF.

\section{Nutritional composition of snack crackers}

The nutritional composition of snack crackers, prepared with different treatment was compared with the control as shown in Table 3 . The ash content of the DCF incorporated cracker samples was significantly higher than the control. The ash content of snack crackers has increased with the addition of DCF concentration The moisture content ranged from 2.16 (30\% DCF) to $2.07 \%$ (control) and moisture content increased with the increase of DCF concentration. The fat content of control crackers was $14.22 \%$ and it was increased up to $14.92 \%$ in $30 \%$ DCF incorporated snack crackers. There was a significant difference in protein content among cracker samples when compared to the control. The protein content of snack crackers ranged from $8.29 \%$ to $7.20 \%$. The cracker samples were showed an increase in protein content when DCF concentration was increased.

With the addition of DCF, the fiber content of the cracker samples was increased significantly $(\mathrm{p}<0.05)$ than that of the control. Results showed that the available carbohydrate content as determined by the difference method was found to be higher in control than that of the DCF incorporated crackers. However, sodium content of the cracker samples was showed more or less similar values for all the cracker samples. With regard to the carbohydrate content, a significant decrease was noticed between the control and DCF incorporated cracker samples. When compared to the control there was a significant increase in energy value of the DCF incorporated crackers.

Functional properties of all purpose wheat flour and defatted coconut flour

Table 3 Nutritional composition of snack crackers out of different treatments (dry basis \%)

\begin{tabular}{|c|c|c|c|c|}
\hline Component & $T_{0}$-Control & $\mathrm{T}_{1}-10 \% \mathrm{DCF}$ & $\mathrm{T}_{2}-20 \% \mathrm{DCF}$ & $\mathrm{T}_{3}-30 \% \mathrm{DCF}$ \\
\hline Moisture & $2.07^{\mathrm{a}}$ & $2.09^{\mathrm{a}}$ & $2.13^{\mathrm{a}}$ & $2.16^{\mathrm{a}}$ \\
\hline Ash & $1.28^{\mathrm{a}}$ & $1.64^{\mathrm{b}}$ & $1.82^{\mathrm{c}}$ & $2.34^{\mathrm{d}}$ \\
\hline Fat & $14.22^{\mathrm{a}}$ & $14.4^{\mathrm{a}}$ & $14.56^{\mathrm{a}}$ & $14.92^{\mathrm{b}}$ \\
\hline Protein & $8.29^{\mathrm{a}}$ & $11.8^{\mathrm{b}}$ & $12.09^{\mathrm{b}}$ & $12.66^{\mathrm{c}}$ \\
\hline Crude fiber & $0.57^{\mathrm{a}}$ & $2.48^{\mathrm{b}}$ & $3.28^{\mathrm{c}}$ & $4.01^{\mathrm{d}}$ \\
\hline *Carbohydrates & 75.64 & 69.68 & 68.25 & 66.07 \\
\hline Sodium & $0.43^{\mathrm{a}}$ & $0.45^{\mathrm{a}}$ & $0.48^{\mathrm{a}}$ & $0.49^{\mathrm{a}}$ \\
\hline Energy & $373.33^{\mathrm{a}}$ & $352.33^{\mathrm{b}}$ & $349.4^{\mathrm{c}}$ & $341.3^{\mathrm{d}}$ \\
\hline
\end{tabular}

The values are mean \pm S.D of three independent determinations. The means with different superscripts in a row differ significantly $(\mathrm{p} \leq 0.05)$.

\section{Physical characteristics of snack crackers}

Physical properties of the cracker samples are shown in Table 4 . With regard to the diameter, there was no difference among all cracker samples and the control However, there was a significant difference $(p<0.05)$ among the DCF

incorporated snack cracker samples and control with respect to the thickness, puffiness and spread ratio. The weight of crackers was ranged from $3.29 \mathrm{~g}$ to 3.55 g. Although results did not show any significant difference in weight among the cracker samples, it was slightly increased with increasing the levels of DCF. The weights of all the cracker samples were higher than the weights of control crackers.

Table 4 Physical properties of crackers out of different treatments

\begin{tabular}{llllll}
\hline Treatment & $\begin{array}{l}\text { Diameter } \\
(\mathbf{c m})\end{array}$ & $\begin{array}{l}\text { Thickness } \\
(\mathbf{c m})\end{array}$ & $\begin{array}{l}\text { Weight } \\
(\mathbf{g})\end{array}$ & $\begin{array}{l}\text { Spread ratio } \\
(\mathbf{W} / \mathbf{T})\end{array}$ & $\begin{array}{l}\text { Puffiness } \\
(\boldsymbol{\%})\end{array}$ \\
\hline Control & $4.37 \pm 0.11^{\mathrm{a}}$ & $0.73 \pm 0.01^{\mathrm{a}}$ & $3.29 \pm 0.34^{\mathrm{a}}$ & $5.94 \pm 0.07^{\mathrm{a}}$ & $4.65 \pm 0.07^{\mathrm{a}}$ \\
$\mathrm{T} 1-10 \%$ & $4.33 \pm 0.06^{\mathrm{a}}$ & $0.70 \pm 0.03^{\mathrm{a}}$ & $3.33 \pm 0.05^{\mathrm{a}}$ & $6.12 \pm 0.18^{\mathrm{a}}$ & $4.44 \pm 0.23^{\mathrm{a}}$ \\
$\mathrm{T} 2-20 \%$ & $4.32 \pm 0.02^{\mathrm{a}}$ & $0.69 \pm 0.06^{\mathrm{a}}$ & $3.43 \pm 0.04^{\mathrm{a}}$ & $6.22 \pm 0.59^{\mathrm{a}}$ & $4.37 \pm 0.50^{\mathrm{a}}$ \\
T3-30\% & $4.24 \pm 0.04^{\mathrm{a}}$ & $0.57 \pm 0.06^{\mathrm{b}}$ & $3.55 \pm 0.11^{\mathrm{a}}$ & $7.43 \pm 0.66^{\mathrm{b}}$ & $3.42 \pm 0.46^{\mathrm{b}}$ \\
\hline
\end{tabular}

The values are mean \pm S.D of three independent determinations. The means with different superscripts in a column differ significantly $(\mathrm{p} \leq 0.05)$.

The changes in width and thickness were reflected in spread ratio which was 5.94 for control snack crackers, these values increased from 5.94 to 7.43 with the rise in the ratio of DCF in snack crackers. Further, there was a significant difference in spread ratio between control and the $30 \%$ DCF incorporated snack crackers The Puffiness of the crackers was significantly lower than that of the control cracker $(p \leq 0.05)$ with the incorporation of DCF for more than $20 \%$ level $(p \leq 0$ $05)$. The thickness and puffiness of crackers made from DCF were decreased with the increase of DCF content in the cracker samples. 


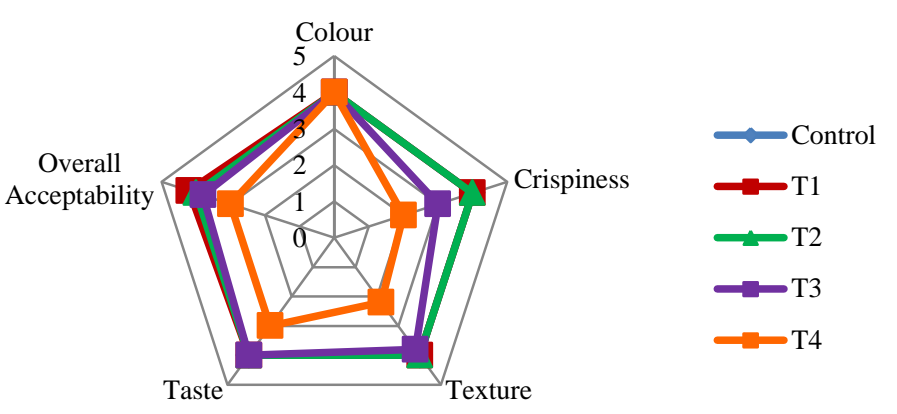

Figure 2 Results of Friedman test along with sum of ranks of sensory attributes

\section{Sensory characteristics of snack crackers}

Results of sensory evaluation in terms of taste, color, texture, crispiness and overall acceptability are presented in Figure 2. It was showed, that similar higher ranks for all attributes for control, 10\% and 20\% DCF incorporated crackers. However, 30\% DCF incorporated crackers showed a significant difference $(\mathrm{p}<0.05)$ in crispiness compared to the control. Mean scores for the crispiness decreased with the increase of DCF content in the cracker samples. Crackers with $40 \%$ DCF had a lower rank for all attributes indicating a low level of preference. There was no significant difference $(\mathrm{p}<0.05)$ among the control and all DCF incorporated crackers with regard to the color. The hard texture was observed by panelists with the rise of the DCF level in the crackers. With regards to taste, up to the level, $30 \%$ cracker samples did not show any significant difference compared to the control and 40\% DCF incorporated crackers showed lower mean scores for taste. Furthermore, there was no significant difference in the control and the cracker samples up to the level of $30 \%$ with respect to overall acceptability.

\section{Shelf life studies snack crackers}

Moisture content is a critical factor which can be affected by the sensory attributes such as texture and crispiness. However, according to the data presented in figure 3 , the moisture content of the cracker samples was increased slightly with time. In addition, the moisture content of the cracker samples was increased with the rise of the DCF substitution level. However, during the entire storage period, none of these samples exceeded the $4 \%$ limit prescribed by the standardization agencies during the 3 months of the storage period (SLS 251: 2010).

The changes in free fatty acid content (FFA) and peroxide values of the cracker samples during storage are shown in figure 4 and 5 respectively. The FFA content of the cracker samples was increased with time. However, during the entire storage period, none of these samples exceeded the $1 \%$ limit prescribed by the standardization agencies (SLS 251: 2010). The FFA content of the cracker samples with 30\% DCF was showed the highest value and the FFA values of the control sample were more or less similar to $20 \%$ DCF incorporated cracker samples. A slight increase was seen in peroxide values of cracker samples with time. Up to the level, 30\% DCF incorporated crackers and control cracke samples were showed higher peroxide values than those of $10 \%$ and $20 \%$ DCF incorporated cracker samples. However, the higher peroxide values did not exceed the maximum peroxide value of $10 \mathrm{mEq} / \mathrm{kg}$ during the 3 months storage.

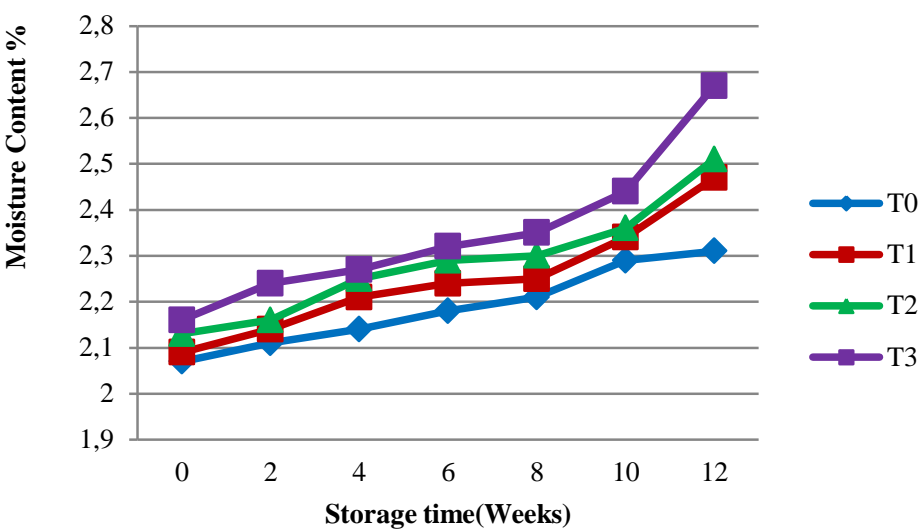

Figure 3 Variation of moisture content in cracker samples with Time

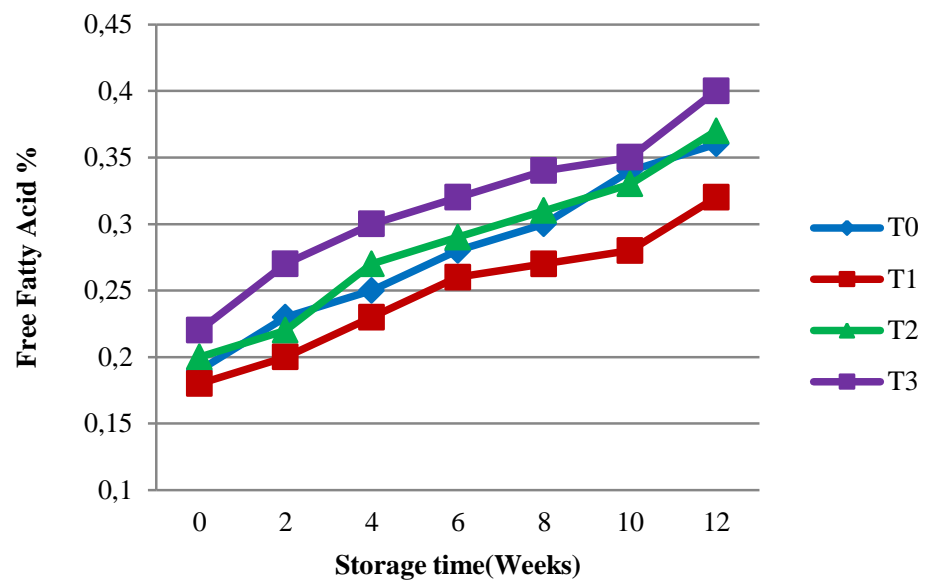

Figure 4 Variation of Free Fatty Acid \% in cracker samples with Time

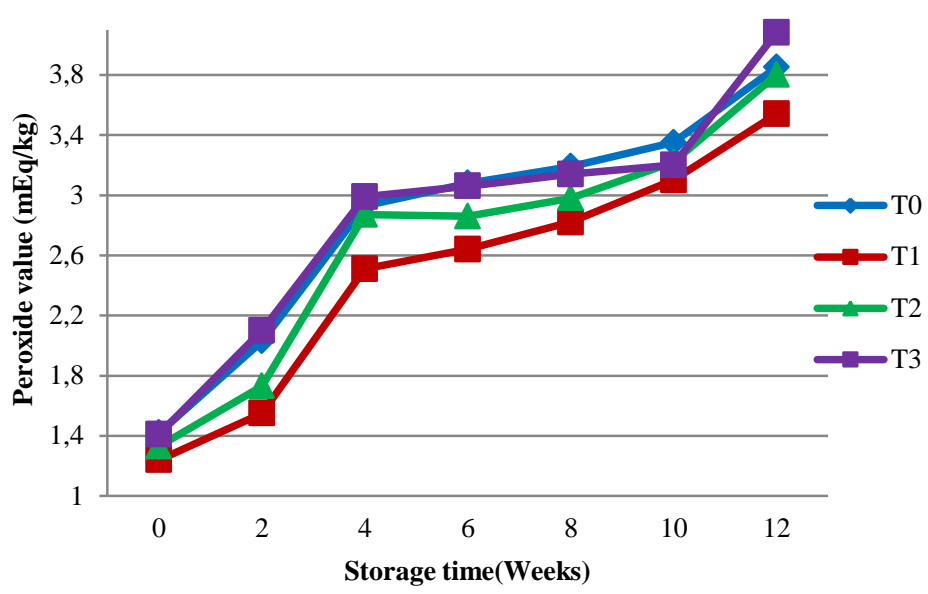

Figure 5 Variation of Peroxide value $(\mathrm{mEq} / \mathrm{kg})$ in cracker samples with Time

According to the test results of the microbial evaluation, the data were showed that there was a slight increase of the aerobic plate count and yeast and mould count of cracker samples during the three months of storage period. The maximum aerobic plate count is $5 \times 10^{4} \mathrm{CFU} / \mathrm{g}$ and maximum yeast and mold count are $5 \times 10^{3}$ (SLS 251:2010). However, the variations were within the tolerable limits.

\section{DISCUSSION}

According to the chemical composition of defatted coconut flour (DCF) and allpurpose wheat flour, it could be stated that defatted coconut flour is contained higher protein, crude fiber, mineral and fat content than wheat flour. The high fat 
content of the DCF illustrates that; it can be more prone to rancidity development during the storage period. Therefore, most suitable packaging and environment should be provided during the storage period for DCF to delay the rancidity development (Lennersten and Lingnert, 2000). Higher content of protein in DCF can be affected by the protein content of the final products and its functional properties. The high moisture content of the WF can be affected by deterioration and mould growth (Fennema and Tannenbaum, 1996). However, the moisture content of the DCF did not exceed the $5.0 \%$ level recommended by the Philippine national standard for the defatted coconut flour (PNS/BAFPS 75:2010). The higher content of ash was contained in DCF revealed that DCF had a higher content of minerals. In addition, the higher crude fiber content of DCF can be affected by the functional properties of DCF.

All the results of the nutritional composition of the DCF in this study were compatible with that of defatted coconut flour produced from the other countries Different methods have been used for analysis of defatted coconut flour composition. The composition of defatted coconut flour depends on the retention of components after the extraction of coconut milk or oil from scraped/desiccated coconut. Therefore, the composition of coconut residue will also change proportionately. According to the Hagenmaier, (1983) the defatted coconut flour is contained $7.6 \%$ of protein, $14 \%$ of oil, approximately $17 \%$ of crude fiber and 5\% moisture. According to Arancon, (1999) nutrient composition of defatted coconut flour was mentioned as; $13.41 \%$ of protein, $2.80 \%$ of moisture, $10.23 \%$ of crude fat and $19.3 \%$ of crude fiber. Trinidad et al. (2006) showed that the dietary fiber content of defatted coconut flour was $60.0 \pm 1.0 \mathrm{~g} / 100 \mathrm{~g}$ sample and out of which $56 \%$ were insoluble and $4 \%$ were soluble. Further, they described that the total dietary fiber content of defatted coconut flour was greater than that of the other dietary fiber source such as oat bran $(8.3 \mathrm{~g} / 100 \mathrm{~g})$ and flaxseed $(28.0 \mathrm{~g} / 100 \mathrm{~g})$. According to the nutritional composition of the DCF, it can be considered as a rich source of dietary fiber, protein and minerals. Therefore DCF can be used as an ingredient to enhance the nutritional value of the food products. DCF has a good potential for the food processing industry.

The functional properties of flour play an important role in the manufacturing of bakery products. The Higher bulk density value of DCF would occupy less space per unit weight. However, WF would be easier to transport as it is lighter and WF would occupy greater space due to lower bulk density. Therefore, it would be required more packaging material per unit weight and could have high packaging cost (Oluwatooyin et al., 2002) compared to DCF. Along with the bulk density is influenced by particle size and the density of the flour and it is important in determining the packaging requirement and material handling. Plaami, (1997) reported that bulk density is influenced by the structure of the starch polymers and loose structure of the starch polymers could result in low bulk density. According to the other studies by Islam et al. (2012) and Olu et al. (2012)o Yam flour $(0.84 \mathrm{~g} / 100 \mathrm{ml})$ and brown rice flour $(0.85 \mathrm{~g} / 100 \mathrm{ml})$ are comparable to that of DCF. According to the Maha et al.(2012), the bulk densities of DCF and WF were lower than that of Soybean flour $(1.85 \mathrm{~g} / 100 \mathrm{ml})$ and pearl millet flou $(1.03 \mathrm{~g} / 100 \mathrm{ml})$. The high bulk densities of the flours suggest of their suitability to be used in various food preparations.

Water holding capacity has been widely studied food functionality due to its importance in food processing. Water plays an important role in the major changes that occur during baking which includes starch gelatinization, protein denaturation, yeast and enzyme inactivation, flavor and color formation (Pomeranz 1985). The higher WHC of DCF may be due to the presence of the high content of proteins and dietary fiber, which represent the major chemical components of DCF. However, the increasing WHC of DCF may be caused by the strong WHC of fibers due to a greater number of a hydroxyl group which exists in the fiber structure and allow more water interaction through hydrogen bonding as reported by Sharoba et al. (2013). In another way, high WHC may be due to the protein and availability of polar amino acids in flour and their degree of interaction with water and their conformational characteristics (Butt and Batool 2010). Niba et al. (2001) described WHC as an important processing parameter that has implications on viscosity.

The oil holding capacity ( $\mathrm{OHC}$ ) of flour is equally important for the flavor. The high $\mathrm{OHC}$ also makes DCF suitable in facilitating the enhancement in flavor and mouth feel when used in food preparations (Appiah et al., 2011). The foaming capacity (FC) is assumed to be dependent on the configuration of protein molecules. Flexible proteins have good foaming capacity, but a highly ordered globular molecule gives low foaming ability (Graham et al., 1976). Food ingredients with good foaming capacity, such as Defatted coconut flour can be used in bakery products. According to all chemical and functional properties of the DCF and WF, DCF has the potential for developing fiber-rich bakery products in order to increase the dietary fiber intake.

The main factors that the consumers are considering prior when buying a product are the sensory attributes. In terms of sensory attributes such as color, taste, texture, crispiness and overall acceptability showed that DCF incorporated crackers were in the acceptable range up to $20 \%$ substitution. The color did not change with the increase in DCF content in the crackers. Broyart et al. (1998) reported that the initial acceptance of baked products is influenced by color which can also be an indicator for the completion of baking. The control and all DCF incorporated crackers were rated for the highest scores by the panelists for the color.
Crispiness is perceived when food is chewed between molars and is usually expressed in terms of hardness and fracturability. Substituting of 30\% DCF affected the crispiness of the crackers, which is an important textural characteristic of crackers. Crackers have become harder and bitter taste when the DCF level was increased in the crackers. This observation could be due to WF substitution with DCF in the crackers formulation, which affects the gluten network in the dough for the development of an open internal structure upon baking. Sudha et al. (2007) also reported similar findings in crackers, prepared from different cereal fiber. The crackers were found to be crispy at the incorporation level of $40 \%$ oat bran, with a very small increase in hardness However, the texture and taste of the crackers would be dependent on the type of flour used for substitution.

Nutrition composition of the crackers was the second important factor that consumers are considering when buying snack foods. The proximate composition of DCF incorporated crackers showed a good nutritional profile when compared to control. The increase in ash content may be due to the high mineral content in the DCF. The relatively higher moisture content of DCF incorporated crackers may be due to high water holding a capacity of the DCF. It will be more prone to deterioration and mold growth than that of the control (Fennema and Tannenbaum 1996). Along with, Ash content is reflective of the total mineral content of the products the results showed that crackers made from the DCF had higher total mineral content. The high fiber content of DCF crackers makes them suitable for the prevention of constipation, colon cancer in humans (Anderson $\boldsymbol{e}$ al., 2009). Therefore, with the incorporation of DCF into the crackers, they were more suitable for the adults and patients who are suffering of the noncommunicable diseases.

According to the nutrient, health claims the fat content of the cracker samples were in the moderate level. Since fat contributes largely to total calories of a diet, health conscious and anorexics patients can eat crackers. Although the fat content was in the moderate level, DCF incorporated crackers were contained good fat profile due to the replacement of virgin coconut oil for the palm oil. Virgin coconut oil is rich in medium-chain fatty acids mainly Lauric acids which do not circulate in the bloodstream like other fats. They are sent directly to the liver and are converted into energy. It stimulates metabolism, boosts energy and prevents deposition of fats, thereby helping to prevent obesity. In addition, it is good for the heart patients as well as diabetic patients (Trinidad et al., 2003).

The total carbohydrate content of the crackers was decreased with the increase in DCF level in the cracker samples. These results were revealed that low caloric intake from the DCF incorporated crackers due to the high fiber content and lower carbohydrate content. However, the obese and those who do not want to gain weight should consider the caloric value of the products when consuming them. Therefore, these DCF incorporated crackers can be consumed by the people who are at risk for the obesity. In addition to that, the sodium content of all cracker, samples were below the limit of "low sodium" statement, according to the nutrient content claims (FAO, 1997). Therefore DCF contained crackers are good for the healthy people as well as patients who are suffering from hypertension.

All the results of the analysis of the nutrient composition DCF incorporated crackers had a good nutrient profile than the control crackers which make them suitable for people of all ages and also for the patients who are suffering from non-communicable diseases. Considering all these facts and according to the nutrient, health claims those DCF incorporated crackers can be considered as healthy crackers.

Incorporation of DCF into cracker biscuits was affected by the physical properties as puffiness, thickness and spread ratio. Those properties were very important for the final appearance of the crackers. There was no effect from the addition of DCF on the shape of the crackers. The thickness of Cracker was decreased with increasing level of DCF. In addition to that, the puffiness of the crackers was showed the expansion ratio of the DCF incorporated crackers. The gluten content is affected to the puffiness of the crackers. Therefore, with increasing the level of DCF in flour blends, the ability to gas retention and expansion of the dough was decreased. The control cracker had the highest puffiness and with the increasing level of the DCF crackers had slightly harder and tougher texture with less expansion than WF. Although results were not shown a significant difference in weight among the cracker biscuits, it was slightly increased with increasing level of incorporating DCF. This might have been due to the greater water-holding a capacity of DCF.

The changes in width and thickness are reflected in spread ratio. Crackers, having a higher spread ratio is considered most desirable (Hussein et al., 2011). This may be due to the increase in fat content in crackers with higher DCF. The similar results were reported with corn and potato flour biscuit (Singh et al. 2003), Oat bran biscuit (Sudha et al., 2007) and raw, toasted wheat bran biscuit (Leelavathi and Rao 1993). Some authors reported that spread factor is highly affected by fat content, as the content of fat increased spread ratio gradually increased (Srivastava and Haridas 1993) or some had been supported this effect due to the increased extension of the dough (Chandrashekara and Shurpalekar 1984). When the DCF level was increased in the crackers; it was adversely affected by the physical properties of the crackers and final appearance of the crackers. 
With all the sensory, physical and nutritional properties of the crackers, there should be good keeping quality during the storage period. According to the present study, chemical changes and microbial changes were in acceptable limit without any adverse effect on the qualities of the crackers during 3 months of period. The moisture content of the crackers is one of the most critical factors for the crackers to keep the good crispiness texture which is important and unique characteristic of crackers during the storage period. The moisture content of all cracker samples was increased with time as well as with increasing the DCF level in the crackers. Hence DCF had a high water holding capacity due to high fiber and protein content. Therefore, DCF incorporated crackers will be more prone to deterioration and mold growth than that of the control (Fennema and Tannenbaum, 1996). The suitable packaging material is one of the solutions for good keeping quality. The triple laminated Aluminum foil was used to store all the cracker samples in this study and it has good moisture barrier properties. However, during the entire storage period, none of these samples were exceeding the $4 \%$ limit prescribed by the standardization agencies during these 3 months of the period (SLS 251: 2010).

As fat was the second largest ingredient of the snack crackers, rancidity development can be happened with resulting unpleasant taste and odor during the storage time. The presence of free fatty acids is an indication of lipase activity or other hydrolytic action and it is a measure of the extent to which the glycerides in the oil have been decomposed by lipase or other hydrolytic action. In this study, the changes of the free fatty acid content of the cracker samples during the storage were in acceptable limit. The FFA content of the cracker samples was increased with the time and with increasing the DCF level in crackers. These changes may be due to the increase in moisture content of the DCF incorporated cracker samples. However, during the entire storage period, none of these samples exceeded the 1\% limit prescribed by the standardization agencies (SLS 251: 2010) and any of samples didn't show the unpleasant taste or the rancid odor.

Peroxide value is another measurement of rancidity development from the autoxidation. Triple laminated Aluminum foil as a good packaging material can be affected to lower values which have light, moisture, gas barrier properties. In addition, control cracker had the higher peroxide value than the DCF incorporated crackers. Hence, the fat source of the control was palm oil and for the treatments, it was virgin coconut oil. This may be affected by the lower peroxide value of the virgin coconut oil added cracker samples. The research found that virgin coconut oil has better antioxidant activity than other oil types based on the oil extraction process which was proven by the analysis of DPHH radical scavenging activity of the cracker samples in this study and Nevin and Rajamohan, (2004) reported that as well. Therefore virgin coconut oil has a good potential to use as a fat source and antioxidants for the cracker production. According to this study, there is a possibility to use virgin coconut oil as natural antioxidants. In general, the greater the degree of unsaturation leads to the greater the liability of the fat to oxidative rancidity (Pearson 1973). Therefore virgin coconut oil is a good source due to the presence of higher amount of saturated fats. Although there was a negative believe about the saturated fat of coconut oil and Marina et al. (2009) found that virgin coconut oil contained medium chain fatty acids and they are good for the human health

Other than that, microbial growth during the storage period is another critical factor for the keeping quality. The present study showed that aerobic plate count and yeast and mould count were lower than the maximum limits as 1000-10000 $\mathrm{CFU} / \mathrm{g}$ and 100-1000 CFU/g respectively. Taheri et al. (2010) found that DCF has an antimicrobial activity to inhibit the microbial growth. In addition, baking temperature influences to the lower values of the microbial counts.

\section{CONCLUSION}

The data presented in this study demonstrate the potential for industria exploitation of defatted coconut flour through processing into snack food items such as crackers. It can be concluded that up to the level of $20 \%$ DCF incorporated crackers were nutritionally rich with good sensory attributes than crackers containing $100 \%$ WF. In addition, the results of this study indicate that DCF may be considered as a potential ingredient for food products, increasing their content of total dietary fiber and improving their technological properties. Hence, development and utilization of such ingredients can be used to improve the nutritional status of the population as well as to overcome non-communicable diseases. The finding of this experiment may help to generate technology to diversify the use of defatted coconut flour by the food processing enterprises, especially baking industries. More studies should be conducted to investigate the possibility of using defatted coconut flour as an ingredient in other food products in order to increase applications of such value-added food ingredient. In addition to that virgin coconut oil can be considered as a good fat source for the food processing as well as it can be used as a natural antioxidant source for the food products mainly for the crackers.

\section{REFERENCES}

Anderson, J.W., Baird, P., Davis, R.H.,Ferreri, S., Knudtson, M., Koraym, A.,Waters, V. and Williams, C.L. (2009). Health benefits of dietary fiber.
Nutrition Reviews, $\quad 67(4), \quad$ 188-205. https://doi.org/10.1111/j.1753-

\subsubsection{9.x}

AOAC. 1999. AOAC Official Methods of Analysis, 14th Ed., Vol. 1, Association of Official Agricultural Chemists, Washington, DC.

AOAC. 1995. AOAC Official Methods of Analysis, 16th Ed., Association of official analytical chemists, Washington, DC, USA.

Appiah, F., Asibuo, J.Y. and Kumah, P. (2011). Physicochemical and functional properties of bean flours of three cowpea (Vignaunguiculata $L$. Walp) varieties in Ghana. African Journal of Food Science, 5(2), 100-104. https://doi.org/10.17660/actahortic.2011.911.51

Arancon, R.N. (1999). Defatted coconut flour.Cocoinfo International, 6(1), 8-10. Baljeet, S.Y, Ritika, B.Y. and Roshan, L.Y. (2010). Studies on functional properties and incorporation of buckwheat flour for biscuit making. International food research journal, 17, 1067-1076.

Butt, M.S, and Batooll, R. (2010). Nutritional and Functional Properties of Some Promising Legumes Protein Isolates. Pakistan Journal of Nutrition, 9(4), $373-$

379. https://doi.org/10.3923/pjn.2010.373.379

Broyart, B., Trystram, G. and Duquenoy, A. (1998). Predicting colour kinetics during cracker baking. Journal of Food Engineering, 35, 351-368. https://doi.org/10.1016/s0260-8774(98)00021-1

Chandrashekara, S. and Shurpalekar, S.R. (1984). Use of Potato and Cassava flours in soft dough biscuits. Journal of food science and technology, 21(4), 239241

Chinma, C.E., Alemede, I.C. and Emelife, I.G. (2008). Physicochemical and Functional properties of some Nigerian Cowpea varieties. Pakistan Journal of Nutrition, 7(1), 186-190. https://doi.org/10.3923/pjn.2008.186.190

Fennema, R.O. and Tannenbaum, S.R. (1996). Introduction to Food Chemistry. In: Fennema, R.O., Karel, M., Sanderson, G.W., Tannenbaum, S.R., Walstra, P., Witaler, J.R. Food Chemistry. Marcel Dekker Inc. New York, pp.1-64.

Food \& agriculture organization of united nations (1997). Guidelines for use of nutrient claims, Nutrition and Health Claims (CAC/GL 23-1997).

Graham, D.E. and Philips, M.C. (1976). The A.Rosniyana conformation of proteins at the air-water interface and their role in stabilizing foam. In Akers, R.J. (Ed.). Foams New York: Academic Press, pp.237-255.

Gunathilake, K. D. P. P., Yalegama, C. and Kumara, A. A. N. (2009). Use of Defatted coconut flour as a source of protein and dietary fiber in wheat bread. Asian Journal of Food and Agro-Industry, 2(3), 382-391.

Gunathilake, K.D.P.P., and Abeyrathne, Y.M.R.K. (2008). Incorporation of Defatted coconut flour into wheat flour noodles and evaluation of its rheological, nutritional and sensory characteristics. Journal of Food Processing and Preservation, 32, 133-142. https://doi.org/10.1046/j.1439-0361.2003.02062.x

Hagenmaier, R. (1983). Dried coconut milk and other new foods from wet process. Coconuts Today, 1(1), 17-24.

Han, J., Janz, J.A.M. and Gerlat, M. (2010). Food Development of gluten-free cracker snacks using pulse flours and fractions. Research International, 43, 627-

633. https://doi.org/10.1016/j.foodres.2009.07.015

Hussein, A.M.S., Amal, S.A., Amany, M.H., Abeer, A.A. \& Gamal, H.R. (2011), Physiochemical sensory and nutritional properties of corn-fenugreek flour composite biscuits. Australian Journal of Basic and Applied Sciences, 5, 84-95.

Islam, M.Z., Taneya, M.L.J., Shams-ud-din, M., Syduzzaman, M. and Hoque, M.M. (2012). Physicochemical and functional properties of Brown Rice (Oryza sativa) and Wheat (Triticumaestivum) flour and quality of composite biscuit $\begin{array}{lllll}\text { made thereof. The } & \text { Agriculturist, } & \text { 10(2), }\end{array}$ https://doi.org/10.3329/agric.v10i2.13135

Leelavathi, K. and Rao, P.H. (1993). Development of high fiber biscuits using Wheat Bran. Journal of Food Science and Technology, 30(3), 187-190.

Lennestern, M. and Lingnert, H. (2000). Influence of wavelength and packaging material on lipid oxidation and colour changes in low-fat Mayonnaise. International Journal of Scientific and Research Publications, 33(4), 253-260.

https://doi.org/10.1006/fstl.2000.0660

Maha, A.M.A., Abdullahi, H.E.T., Abd, O.E., Limya, O.M. and Babiker, E.E. (2012). Effect of Different Supplementation Levels of Soybean Flour on Pearl Millet Functional Properties. Food and Nutrition Sciences, 3, 1-6. https://doi.org/10.4236/fns.2012.31001

Marina, A.M., Man, Y.B.C. and Amin, I. (2009). Virgin coconut oil: emerging functional food oil. Trends in Food Science \& Technology, 20, 481487. https://doi.org/10.1016/j.tifs.2009.06.003

Nevin, K.G. and Rajamohan, T. (2004). Beneficial effects of virgin coconut oil on lipid parameters and in vitro LDL oxidation. Clinical Biochemistry, 37(9),

830-835. https://doi.org/10.1016/j.clinbiochem.2004.04.010

Niba, L. L., Bokanga, M. M., Jackson, F. L., Schlimme, D. S. and Li, B.W. (2001). Physicochemical properties and starch granular characteristics of flour 
from various Manihotesculenta (Cassava) genotypes. Journal of Food Science, 67(5), 1701-1705. https://doi.org/10.1111/j.1365-2621.2002.tb08709.x

Okaka, J. C. and Potter, N. N. (1977). Functional and storage properties of cowpea-wheat flour blends in bread making. Journal of Food Science, 42, 828833. https://doi.org/10.1111/j.1365-2621.1977.tb12614.x

Oluwatooyin. F, Osundahunsi. A, Aworh. C. (2002) A preliminary study on the use of tempe-based formula as a weaning diet in Nigeria. Plant Foods for Human Nutrition, 57(3), 365-376. https://doi.org/10.1023/a:1021805117084

Olu, M., Ogunmoyela, O.A.B., Adekoyenii, O.O., Jimoh, O., Oluwajoba, S.O. and Sobanwa, M.O. (2012). Rheological and Functional Properties of SoyPoundo Yam Flour. International Journal of Food Science and Nutrition Engineering, 2(6), 101-107. https://doi.org/10.5923/j.food.20120206.01

Pearson, D. (1973). Laboratory Techniques in Food Analysis, Butterworths\& Co Ltd, London, England.

Philippine National Standard PNS/BAFPS 75 (2010) Defatted coconut flour specification.Member to the International Organization for Standardization (ISO).1-6.

Plaami, S.P. (1997). Content of dietary Fiber in Foods and its physiological effects. Food Review International, 13, 27-76 https://doi.org/10.1080/87559129709541097

Pomeranz, Y. and Meloan, C.E. (1987). Food Analysis: Theory and Practice 2nd ed. Van Nostrand Reinhold, New York.

Singh, J.N., Singh, T.R., Sharma and Saxena, S.K. (2003). Physicochemical, rheological and cookie making properties of Corn and Potato flours. Food

Chemistry, 83(3), 387-393. https://doi.org/10.1016/s0308-8146(03)00100-6

Sharoba, A.M., Farrag, M.A. and Abd el-salam, A.M. (2013). Utilization of some fruits and vegetables waste as a source of dietary fiber and its effect on the cake making and its quality attributes. Journal of Agroalimentary Processes and Technologies, 19(4), 429-444

SLS 251: 2010, Specification for biscuits, Sri Lanka Standard Institution, Colombo, Sri Lanka.

SLS 256: 1991, Micrbiological Test Methods, Sri Lanka Standard Institution, Colombo, Sri Lanka.

Sosulski, F.W., Garratt, M.O. and Slinkard, A.E. (1976). Functional properties of ten legume flours. International Journal of Food Science and Technology, 9,

66-69. https://doi.org/10.1016/s0315-5463(76)73614-9

Srivastava, A.K. and Haridas, R.P. (1993). Studies on low-fat soft dough biscuits Journal of Food Science and Technology, 30(1), 21-24.

Sudha, M.L., VetrimanI, R. and LeelawathI, K. (2007). Influence of Fiber from Different Cereals on the Rheological Characteristics of Wheat Flour Dough and on Biscuit Quality. Food Chemistry, 100(4), 1365-1370. https://doi.org/10.1016/j.foodchem.2005.12.013

Taheri, J.B., Espineli, F.W., Hans, L., Maryam, Bakhshi, A., Nakhostin, M.R and Hooshmand, B. (2010). Antimicrobial effect of Defatted coconut flour on oral microflora: An invitro study. Research Journal of Biological Sciences, 5(6), 456-459. https://doi.org/10.3923/ribsci.2010.456.459

Trinidad, P.T., Mallillin, A.C., Valdez, D.H., Loyola, A.S., Askali-mercado, F.C., Castillo, J.C., Encabo, R.R., Masa, D.B., Maglaya, A.S. and Chua, M.T. (2006) Dietary fiber from Defatted coconut flour: A functional food. Innovative Food $\begin{array}{llll}\text { Science and Emerging Technologies, 7, 309-317. } & \text {. }\end{array}$ https://doi.org/10.1016/j.ifset.2004.04.003

Trinidad, P.T., Divinagracia, H.V., Anacleta, S.L., Aida, C.M., Faridah, C.A., Joan, C. C. and Dina, B.M.(2003). Glycaemic index of different coconut (Cocosnucifera)-flourproducts in normal and diabetic subjects. British Journal of Nutrition, 90, 551-556. https://doi.org/10.1079/bjn2003944

Valencia, V.N., GranadoS, P.E., Agama, A.E., Tovar, J., Ruales, J. and Bello, P.L.A. (2006). Fiber concentrate from mango fruit: Characterization, associated antioxidant capacity and application as a bakery product ingredient. Lebensmittel$\begin{array}{lll}\text { Wissenchaft } & \text { und-Technologie, }\end{array}$ https://doi.org/10.1016/j.lwt.2006.02.028

Williams, F.L., Mwatsama, M., Ireland, R. and Capewelll, S. (2008). Small changes in snacking behavior: the potential impact on CVD mortality. Public Health Nutrition, 12, 871-876. https://doi.org/10.1017/s1368980008003054 